\title{
ONE TALE FOR FOUR AND NEW MORALS FOR OLD: THE CONSTRUCTION AND THEMES OF E. NESBIT'S “THE MAGICIAN'S HEART"
}

\author{
Sanjay Sircar
}

\section{INTRODUCTION}

It has been said that at the end of the Victorian period when "it was becoming more and more difficult ... to write new fairy stories that were not just copies of the old", E. Nesbit (1858-1924), who was "serious even at her most fantastic and hilarious", "discovered exactly the right mixture of mirth and magic" within the popular genre of the British Kunstmärchen (art-fairytale) (Green 1955: xv-xvi). This article examines Nesbit's short burlesque Kunstmärchen for children, "The magician's heart", in order to show how this new sophisticated fairy story draws upon old traditional ones, but is more than a copy of them in its introduction of new inflexions, tones and values into the traditional material of its sources. Folklorist Antti Aarne's account of the processes of Märchen mutation over time and space and language, an unsuperseded basic account of these processes, provides a framework against which the assembling of this or any modern Kunstmärchen can be considered.

"The magician's heart" is the last piece in The magic world (1912), Nesbit's last volume of short fantasy pieces collected in roughly chronological order. ${ }^{1}$ In it, Professor Taykin, a wicked magician, curses Prince Fortunatus with stupidity and Princess Aura with ugliness at their christenings, and is imprisoned in a tower. Aura eventually dupes Taykin into making her beautiful, makes Fortunatus (who has become Taykin's apprentice James) clever, and refuses to marry Taykin. She escapes to the palace, followed by Taykin and James. Taykin becomes the palace cook, leaves his separable heart on a shelf and drops his magic book. James purloins both. Aura enters, Taykin threatens to re-uglify her, James blackmails him with the heart, and Taykin is taken to the King. Taykin 
gains his life by telling the King that Aura will not marry any suitor he has picked out for her because she loves his apprentice. Aura's father makes her promise to marry the suitor on her right hand in return for sparing the life of Fortunatus/James on her left, Fortunatus reverses their positions by the magic in Taykin's book, and thus outwits the King. Fortunatus turns Taykin into a child, and the young pair marry.

The British Kunstmärchen tradition derives from the European secondary tradition of Märchen, that is, the tradition of short oral retellings followed by Perrault and the Brothers Grimm and then given to nineteenth- and twentieth-century children (Scherf 1974: $80-81$ ). This tradition always interpenetrated with printed versions, for there is no such thing as a purely oral tradition in Europe (Brereton 1957: xiv). Kunstmärchen are part of the larger category of "second-order" literature, not an evaluative term, purely a descriptive one, which describes work that can be called "parody" in the broadest sense, that is, literature which has a self-conscious, foregrounded relationship to previous literary material, and which is not necessarily comic or mocking. Till very recently indeed, second-order works generally, and Kunstmärchen in particular, have been neglected because they have been considered minor (because "derivative") work.

Empirically, English Kunstmärchen come in the allegorical, romantic or burlesque varieties; and the burlesque Kunstmärchen, as lowcomic derivative work within the sphere of popular rather than high culture has occupied a particularly low status (many of Nesbit's Kunstmärchen were first printed in the Strand Magazine, a middle-class family periodical). "The sleeping beauty" is central to the entire Kunstmärchen tradition and "Sleeping beauty" Kunstmärchen "reversions" (as distinct from "versions" in the sense of "retellings") are so numerous that Barbara Wall, secure that her readers will know instantly what she means, can refer to "variations of the story of the wicked fairy at the christening" (Wall 1991: 74). Many "Sleeping beauty" Kunstmärchen are burlesque tales, as are most of Nesbit's corpus of Kunstmärchen (though a few have an allegorical or romantic flavour), and Nesbit wrote many "Sleeping beauty" Kunstmärchen. "The magician's heart" is a "Sleeping beauty" 
Kunstmärchen, a representative of the burlesque variety, and epitomises Nesbit's work in the genre.

The teller of a Märchen sets out to retell an old tale, while the writer of a Kunstmärchen sets out to make a new one. The "easily detectable" mutations over anonymous "folk" retellings of a Märchen occur "by chance" are "natural" and "gradual" and the tale itself remains the same though the words and some features change (Aarne 1913: 38-39, 23). But an individual "popular" writer's changes to Märchen material in a Kunstmärchen are deliberate and instantaneous and result in a different tale, be it a pastiche of isolated motifs, or, like "The magician's heart", a contaminatio of entire tale-types or tales (as in the Roman comic drama). Contaminatio is relatively rare in "Sleeping beauty" Kunstmärchen (an exception being Andrew Lang's Prince Prigio, 1889, which conflates it with "The Dragon Slayer" etc.), but is a generic burlesque Kunstmärchen technique, often used in pantomime.

The most important process in the retelling of a naive Märchen is the forgetting of details, then amplification at any point with new material which must have an overall complementarity with the original tale, frequently derived from other similar Märchen, often resulting in a literary doublet of similar episodes. Conflation results in the process of (what might be called) "harmonisation" in Märchen mutation, whereby a change in one part of the tale, particularly with the introduction of imported elements, necessitates changes (eg. substitutions) to the other parts (Aarne 1913: 23-24, $24-26,28-30,35)$. Because of amplification by similar segments, this sort of retold Märchen does not draw attention to the process of its construction out of other Märchen.

But an analogous sophisticated Kunstmärchen, as second-order literature, does indeed draw attention to the process of its construction, with its juxtaposition of two disparate kinds of tales. "The magician's heart" conflates four "tales of magic" within the "ordinary folk tale". As a mutating Märchen would, its first part, set largely in Taykin's tower, conflates material from two similar tales of the "supernatural or enchanted husband (wife) or other relative", primarily "The sleeping beauty" (AT 410), and secondarily Perrault's lighter "Rickey with the tuft" (not an independent tale type, but a variation of "The sleeping beauty"). Its second part, set in the pal- 
ace, similarly conflates material from two "supernatural adversary" tale-types, primarily "The ogre's (devil's) heart in the egg" (AT 302) and secondarily the lighter "The magician and his pupil" (AT 325, $\left.325^{*}\right)$. With harmonisation and substitution, Taykin "is" the prototypes' enchanter/curser-fairies, magician, and ogre. Fortunatus/ James and Aura "are" the high and lowly placed princes and lowly born young man, and passive and active princesses. Taykin is the adversary of the King and the royal babies in the first segment, but the King takes over and shares Taykin's function as older male adversary of youth in the last, without disharmony.

Within the parts the conflation is like that of Märchen mutation, but the two parts themselves join "enchanted relative" and "supernatural adversary" tale-types which are not intrinsically similar to each other, when the new protagonists interact with their adversary. These two sets of tales would probably not have been joined in any unselfconscious oral telling of any one of the prototypes, and their juxtaposition calls attention to the fact that old Märchen have been joined together to make this new elaborated Kunstmärchen. This contaminatio-conflation is not a matter of reduplicated segments, intercalation of the prototypes' plot strands. "The sleeping beauty" and "Rickey" begin and proceed together, and end with the curse-nullification. Before this, "The magician and his pupil" begins, when Taykin takes on his apprentice, and between nullification of one curse and another, "The ogre's heart" begins, when Taykin reveals his separable heart. "The ogre's heart" ends first, with James's blackmail, "The magician and his pupil" last, with Taykin being transformed. This plot-intercalation is not Märchenlike.

Part of the point of a Kunstmärchen may lie in its self-conscious relation to its inherited traditional materials, and I will consider Nesbit's formal techniques of prototype-conflation. These techniques are like the unselfconscious processes of Märchen mutation, which may be grouped into the general categories of forgetting, amplification, substitution and harmonisation, but they work to different ends. They here result in a narrative with a plot which overtly derives from Märchen but is unmistakably not one, as it sophisticatedly varies its inherited materials to introduce alien inflexions of gender and class, comic tones, and partially reverses their values 
by substituting the sinister, brutal and the punitive with the pathetic and compassionate. It is these alien elements which generically differentiate the new Kunstmärchen from the old Märchen genre and material which it recalls and self-consciously parodies.

The cursed ones, curses and curser of "The sleeping beauty" and "Rickey with the tuft"

\section{FORMAL DOUBLING AND SUBSTITUTION AND THEMATIC GENDERED INFLEXIONS}

"The magician's heart" retains and plays with ("mutates") the basic plot of "The sleeping beauty", probably the tale most commonly drawn upon by Kunstmärchen, familiar to British children's literature through translations and retellings of Perrault and less so of the Grimms. If we generalise the list of folktale motifs which comprise "The sleeping beauty" we get: a royal christening, a particular christening curse ensuring an obstacle to the protagonist's happiness, a supernatural curser with a specific motive, a mitigation of the curse, an attempt to avoid its fulfilment, its fulfilment, and the breaking of the curse by a character inspired by curiosity and bravery and love (this omits Part II of the tale, with the ogress mother, as Perrault has it). As with all Märchen, a range of implications (but not an unlimited one) can be suggested by or drawn from this basic tale: eg. the inevitability of misfortune, the power of fate, the use of patience, the inevitability of happiness, the triumph of time (the right prince will come at the right time though others might try in between), the awakening of nascent sexuality, the overcoming of winter by the sungod in spring, the power of heroic bravery and the power of love (see Lüthi for Jungian and other interpretations: Lüthi 1970: 161-162).

One of the processes of Märchen mutation is amplification by multiplication of persons (or objects, functions, incidents, etc.), often by particular numbers (eg. three, five or seven) (Aarne 1913). So, for example, over versions the number of good fairies at the christening of the Sleeping Beauty is variously three, seven or twelve. "The magician's heart" seems to double the Sleeping Beauty into Fortunatus and Aura, and add comic inflexions to the way in which 
they are depicted. All narrative doubling need not be comic, but a certain sort of doubling in Kunstmärchen marks artificiality and often is comic, so here, baby Prince Fortunatus is in blue satin, baby Princess Aura is in pink velvet (details alien to the Märchen), both are cursed by Taykin's mental spells, and the Prince becomes a scullion and the Princess a beggar maid, and each goes on to reveal to the other their royal status.

But it is not Fortunatus's but Aura's christening which actually corresponds to that of the Sleeping Beauty, and Aura is the main protagonist of the first part. At Aura's christening, the White Witch (absent at Fortunatus's) corresponds to the good fairy of "The sleeping beauty". At the Sleeping Beauty's christening, the good fairy saw the evil fairy's muttering, mitigated her curse though she could not annul it, prophesied that it would end and the means of its ending (the arrival of a prince), and at the time of the fulfilment of the curse she put the household to sleep and made the thorn hedge grow. Likewise, the White Witch sees Taykin's cursing and preparation to vanish, prevents him from disappearing, bestows a magic kiss (indirectly) to mitigate the curse though she cannot annul it, prophesies that it will end and how (through Taykin himself), and advises the King to imprison Taykin but not to kill him. An imperfect correspondence with the attempt to avoid the fulfilment of the curse in "The sleeping beauty", the Sleeping Beauty's father forbidding all spinning in his country, is the banishment by Aura's father of all magicians except Taykin.

However, the nature of neither obstacle-curse relates to fate or nascent frozen sexuality. The curse of "The sleeping beauty" has not only doubled, but been substituted by a mental defect, Fortunatus/ James's stupidity, and a bodily one, Aura's ugliness. The curse of ugliness is fairly traditional. Some of the heroines in Mme d'Aulnoy's Kunstmärchen (or hyper-sophisticated retellings of Märchen, familiar in England as Mother Bunch's Tales) are similarly cursed, and Nesbit used a doubled curse of ugliness in "Belinda and Bellamant" before she wrote "The magician's heart".

If "The magician's heart" doubles the curses of "The sleeping beauty", this doubling is heavily influenced by the doubling already present in Perrault's "Rickey with the tuft", which was reconstituted from a literary source (Brereton 1957: xxxvi-xxxvii), and is much more so- 
phisticated in characterisation and motivation (no evil fairy, only a good one), and much more playful than "The sleeping beauty", as an allegorical account of the psychology of love, and much less schematic than an ordinary Märchen in its three natural (not curse) birth-afflictions of ugly Prince Rickey and of two sisters, stupid and ugly princesses. Only this Märchen, of the ones well-known to English children, gives us corresponding afflictions at birth in which the customary curse-mitigation of "The sleeping beauty" involves the potential transferability of blessings, the counterposition of stupidity to ugliness, compensating blessings (wit for ugliness, beauty for stupidity), and a mutual rescue.

A Märchen can multiply a protagonist over retellings, and as it mutates, an external element can substitute for one originally in a tale, a quality once attributed to one figure can be reattributed to another, and the relation or the attributes of two opposite (contrasted) figures can be substituted for each other (Aarne 1913: 32). But the new protagonists are rarely new figures with relatively independent plots. As a burlesque Kunstmärchen, "The magician's heart" primarily plays formally with the Märchen material of the "enchanted relative" tales, in comic doubling of protagonists, and substitution of attributes. In place of the prototypes' complementary lovers, the active rescuing males and passive cursed and rescued females in relatively uni-linear and schematic plots, it provides a male and a female in corresponding, parallel, equal and intersecting curse-plots, who are equally active and passive and mutually helpful. Aura is more active in the first part, Fortunatus/ James in the second. Granted, "The magician's heart", like "The sleeping beauty", can be taken to reinforce traditional patriarchal notions of romantic love, of an ultimately benevolent providence, of a happy conclusion after a necessary hiatus of "all these years", of $\mathrm{Mr}$ or Miss Right, of the power of love at first sight to inspire selfsacrifice which overcomes all deathly obstacles, and of princesses who help their princes. Nevertheless, it also introduces some feminist inflexions which move some distance away from the Märchen's traditional, sometimes manifestly patriarchal world-view.

Its reattribution of attributes reverses traditional active/passive gender roles as it puts Aura's christening gift (the magic kiss to be used later), in place of the prince's curse-breaking spell-dispelling 
magic kiss (a motif common in Nesbit, which is in many versions of "The sleeping beauty" but not actually in Perrault, and though it appears in the Grimms, it does not itself break the curse, the right time does). Where Rickey falls in love with a picture of the stupid princess before he meets her, Nesbit makes this mutual when the pair see dreams and visions of each other. "Rickey" implies that beautiful stupidity is feminine and clever ugliness is masculine (its clever ugly attractive princess does not marry), and Nesbit reverses as James gets "beauty" (a more feminine word than handsomeness), and Aura is ugly but clever (both her clever Cousin Belinda and her clever husband Bellamant have also previously sought beauty). Advised by a female (Cousin Belinda), Aura is an admirable female trickster-figure, active and ingenious for herself as well as for love of another, as she deceives Taykin.

In "Rickey", schematically and without suspense, the beautiful stupid princess passively waits to be helped, and told how to help Rickey by him, but Nesbit extends this in the mutually active love of Aura and Fortunatus, which a much more complicated flow of cause-andeffect. Fortunatus's has no transferable magic gift, but his other christening gifts of "strength and goodness", which seem to be as peripheral as those given to the Sleeping Beauty, turn out to be significant "narrative hook" alien to the Märchen. He gives "beggar maid" Aura his last tuppence and she sees, "You are good". He is too stupid to be able to open the lock on the door to let her out; she is too weak, but she can directly give him wit to help both as he too now becomes a clever trickster, and can use both own strength and her wit to let her out, and then blackmail Taykin and outwit the King while Aura helps him by getting the King to spare his life in exchange for her filial obedience.

All "Sleeping Beauty" Kunstmärchen can vary the prototype's motifs to put forward their own moral implications. The power and importance of amoral ingenuity is not even potentially a lesson in "The sleeping beauty" or "Rickey", but often in Nesbit's "Sleeping Beauty" Kunstmärchen, love ingeniously finds a way to remove christening curses. It is witty instances of this that are Nesbit's forte (eg. in "Melisande"), and constitute her characteristic (and most original) contribution to the English Kunstmärchen. Thus, "The magician's heart" substitutes different christening curses from those 
of its prototypes, and different means by which they are lifted. Through these new means, "The magician's heart" presents female initiative, then mutually active and mutually ingenious love which has flow-on effects, as exemplary. In Märchen mutation, the two important processes of "harmonisation" are acclimatisation of alien matter by naturalising foreign elements (eg kinship-forms, morals, setting or religion) and modernisation of archaic ones, but the main part of the Märchen retains its meaning (Aarne 1913: 36-37, 3738). Similarly, Nesbit's ideological gendered changes to her "enchanted relative" prototypes result in a difference in emphasis rather than an entire change in meaning, but this difference prepares for the radical differences from their prototypes which are seen in late twentieth-century feminist Kunstmärchen and Märchen retellings.

\section{FORMAL SUBSTITUTION AND THEMATIC CLASS/ PSYCHOLOGICAL INFLEXIONS}

Techniques corresponding to the processes of amplification by multiplication, substitution by function-reversal, and harmonisation of old and alien elements seem to bring into narrative being the young lovers of "The magician's heart", whose traditional gendered roles change, but not their social station. Other ontological processes of substitution in Märchen mutation replace one kind of character by another, while their functions usually remain the same: there can be specialisation of a general term (mouse for animal), polyzooism (many animals for one), anthropomorphism, therio- or zoomorphism (man into animal), demonisation of animals, and egomorphism (which makes the hero the narrator) - and the reverse (Aarne 1913: 30-34). Nesbit's corresponding ontological substitution for the female evil fairy of "The sleeping beauty" makes her Kunstmärchen curser, Taykin, male and human and working-class.

Naturalisation and modernisation in relation to Taykin are particularly important for reasons of generic decorum. "The magician's heart" is a burlesque genre parody, so techniques like the processes of naturalisation and modernisation also work within it towards a comic effect which is alien to the Märchen itself, which does not naturalise and modernise for comic play. Furthermore, "The magician's heart" uses the second-order art of parody to provide a shift 
of perspective or a new angle on something suggested by an original, as, indeed, does other second-order literature within children's literature (eg. Jan Needle's Wild Wood which looks at the place of the underclass in The Wind in the Willows, or a recent sequel to Tintin which comments on the conventions of long-running serials with unchanging characters, as the ever-young reporter grows up and marries). This shift of focus to a supernumerary figure in a prototype is one of the techniques of parody (eg. Rosenkrantz and Guildenstern are Dead, which takes a knowledge of Hamlet for granted and shifts focus to the prince's friends), and "The magician's heart" shifts the focus of "The sleeping beauty" to direct interest away from its prototypes' traditional enchanted protagonist(s) to the enchanter/curser.

The evil fairy who appears once at the christening in both the Perrault and Grimm versions takes on in other later versions (including the Disney film, 1958) the disguise of the old woman on whose spindle the Sleeping Beauty pricks her finger. Nesbit's semi-burlesque retelling of "The sleeping beauty in the wood" itself in The old nursery tales (1908) calls the evil fairy Malevola, as do some of her "Sleeping Beauty" Kunstmärchen. Her version of gives Malevola bats' wings and a bonnet rimmed with live snakes (the sartorial features used to describe the second evil fairy in "Melisande" seven years earlier), and this Malevola disguises herself as the old spinning woman, and dies of spite at the end when the lovers are united. She appears with the accompaniment of thunder and lightening, much as Taykin disappears like the traditional pantomime Demon King, "in a puff of red smoke" and the smell of fireworks. This Malevola and Taykin share the generic broad comic characterisation of the burlesque Kunstmärchen.

But Taykin is much more in evidence than the Malevola of "The sleeping beauty" or any other Nesbit evil fairy, and unlike them, we see him for long sections after he has done his cursing. The characterisation of Taykin modifies the externalised, functional, unidimensional flat characterisation of Märchen with some psychological touches, and it also makes a social point. It goes too far to say that, like her feminism, "Nesbit's contribution to the fairy tale as a literary form - her use of rounded characters, her social relevance - is great" (Armstrong 1974: 116, 141). Nesbit's characters 
in her Kunstmärchen are not in any novelistic sense "rounded", nor is the degree of depth with which she depicted them anything new (it was anticipated much earlier by Thackeray, Lang and Hood). Likewise, despite her Fabianism, the social relevance of her work is often not much more than a flourish. There are glaringly unresolved snobberies about the vulgarities of the lower classes and the hypergentility of the lower-middle classes in, for example, The enchanted castle (1908) or The lark (1921), and one can overstress her feeling for the poor (Ellis 1974: 72-79), and her Utopianism (Rahn 1985).

Nevertheless, through Taykin, “The magician's heart" lightly makes socio-psychological points which are different from those of the "The sleeping beauty" and which are at variance with the world-vision of the prototype's genre. The motivation of the evil fairy of "The sleeping beauty" is the understandable short temper of old age and angry insult that her right to be invited to the royal christening has been ignored. She is genuinely forgotten in Perrault, so there is no proper place setting for her; she is deliberately not invited in Grimm, for that reason itself. Taykin's motives seem initially to be the same as the wicked fairy's, for "he always expected to be invited to the christening parties of all the royal babies, and of course he never was', but his grievance is not a justified one, for he has no right to an invitation to a royal christening, no right to social privilege and place. The very next clause clarifies that he was not invited "because he was not a lord, or a duke, or a seller of bacon and tea, or anything really high class, but merely a wicked magician" of whom no court would know or take account. Taykin as magician, that is conjurer, is thus like a traditional mountebank, lower even than a merchant or tradesman, an emblem of the ignored worker in a hierarchical class society; while as "Professor", he is also an emblem of the disaffected intellectual. Both are "politely" ignored as the "outsider" (an upperclass word for lower-class "bounder") which Taykin literally is at Fortunatus's christening. The class-inflexions for his revenge-curses, directly opposite to the Wicked Fairy's aristocratic sense of being insulted, explain and extenuate his malice.

A connection between the Victorians' interest in heredity and the widespread christening curse motif in Victorian Kunstmärchen has been suggested (Croxon 1971), and the possibility of this link is borne 
Sanjay Sircar

out by one of Nesbit's many fervently Fabian verses, "A last appeal" (which appeared in at least two of her collections). In this poem the workers appeal for their share of the physical necessities of life. They call out their threat of revenge and their words link low birth, prostitution or droit de seigneur, heredity, venereal disease. The workers make the appeal of belonging to a common species with their masters, "Brothers in nature, pulse, passions and pains"; they say that "Our sins [are] in you, and your blood in our veins". They cry out, "What is the least common manhood can claim?", and they answer, "Food that we make for you,/Money we earn:/Give us our share of them -/Give us our turn." If they are disregarded, they say, God's patience will run out, He will use the workers as His weapon to tread their masters down, the "appeal that...[they] spurned [will] be new-born as command" and the masters will "die by the rod/Of the vengeance of man through the justice of God" (Nesbit 1887: 93; Nesbit 1908: 40-42). Thus, in the context of Nesbit's other work, "The magician's heart" encourages a production of a reading that takes Taykin's christening curse as the revenge of the worker, who is and who knows he is of the same humanity as his superiors but is denied his "turn" at (his share of) a psychological necessity of life, dignity and social acceptance.

Taykin intertwines a class theme with a theme of personal wickedness; he has both a social and a psychological dimension. He is characterised like Uriah Heep: the character is wicked, but the reasons are understandable, and both a social system as well as a personality are blamed for it. Taykin is socially undesirable not only because he is a low-class magician, but also because he is a wicked one. His spleen dominates his whole personality, and makes the point that contempt and isolation can result in rooted hostility. "Born quite good", but loved only by his nurse, Taykin "had changed since he was a boy, as a good many other people do - perhaps it was his trade". It is not the isolated study or hermetic investigations of that trade that have changed him, but the contempt of other people to it. Ostracism breeds delight in the negative exercise of power: Taykin was "very glad to think that he had made such a lot of people unhappy" in his revenge, and looks forward to inflicting more unhappiness. Ostracism also breeds perverse stubbornness: the White Witch tells the King that Taykin is "the only person who can make the Princess beautiful again... But don't you go asking him to do it. 
He'll never do anything to oblige you. He's that sort of man", and the townsfolk refer to him as a "spiteful chap".

But there are indications to the contrary in his politeness to his visitors and hospitality to his old nurse who comes to visit him in his imprisonment. He is a pathetic figure, not a frightening one like his prototype, as he says to her, "I've lived here alone for twenty years. It's very lonely, especially of an evening...", ““It's a dog's life." He sniffed....and wiped his eyes." This is a version of the common Victorian motif that fearsome power turns out to be pathetic crusty loneliness when you meet it and see it for what it is: Frances Hodgson Burnett's Little Lord Fauntleroy, Alcott's Little women, Mrs Molesworth's "The story of Sunny" in A Christmas child, Baum's The wonderful wizard of $\mathrm{Oz}$. And "The magician's heart" makes the general point that the psychological misanthropy bred of ostracism can become ineradicable. At the end, in danger of his life and powerless to inflict any more harm, Taykin is exhorted to mend his ways and "be good". He replies, "I won't; and what's more, I can't". Fortunatus says, "No one can be made good by magic", and it takes the artificial magic of an authorial magic wand to reverse Taykin's wickedness, as Fortunatus takes the badness out of Taykin instead. Thus, in the turning of the aristocratic rage of the curser into the humiliated anger and deep-seated spite of the lowly conjurer, "The magician's heart" holds out a warning that it may one day be too late for the workers to be exhorted to reform and "be good", that the psychological damage done by social exclusion may be unchangeable except by a miracle.

\section{THE WEAK AND THE STRONG OF "THE MAGICIAN AND HIS PUPIL” AND “THE OGRE'S HEART IN THE EGG”}

\section{Formal modification of traditional motivation, tonal replacement of the sinister by the comic}

With the "enchanted relative" tales Nesbit plays with the ways in which the enchantment-curse is broken, shifts the focus from their princess and prince onto the reasons for the enchantment and onto the enchanter (curser), as her title indicates. The prototype tales of the second part, primarily "The ogre's heart in the egg" and second- 
arily "The magician and his pupil", tales of the "supernatural adversary' themselves, are both about a weak male youth growing up and dealing with a powerful father-figure (Nesbit also used both prototypes in "Septimus Septimusson', coll. 1912, and "The ogre's heart" in "The charmed life", coll. 1905). The young man appears to accommodate the father-figure, then confronts and challenges him, tests his strength against him, overcomes him and is rewarded by possessing the helpful young girl. Just as Nesbit retains something like the traditional morals about love, time, providence and mutuality with the first two prototypes, but introduces further gender and class inflexions, she retains the traditional morals about how youth attains maturity through struggle with the second two prototypes. But she plays with and modifies the traditional situations, softens the sinister and the brutal motives and qualities of the supernatural adversary and the ways in which youth deals with him, in order to replace the archaic punitive values and moral order of the Märchen with softer, more modern ones which are alien to it. Here again, the Kunstmärchen writer's techniques in deliberately altering old material naturalise the foreign and modernise the archaic elements in the prototypes.

James's situation and plot as Taykin's apprentice derives from "The magician and his pupil", also called "The sorcerer's apprentice", probably of Indian origin (Cosquin 1912: 337-373, 393-430, 497-526, 545566), collected by the Grimms, and found with its variant, "Apprentice and Ghost" (Tale Type 325*), in many parts of England. In "The magician and his pupil", a sorcerer takes a stupid boy as his apprentice, but the boy learns the art of magic and surpasses and overcomes his master in the display of virtuosity in a transformation combat, aided by a princess on whose finger he takes refuge as a ring. The charwoman's shadow (1926), by Nesbit's friend Lord Dunsany, is a modern elaboration of the situation of the sorcerer's apprentice into a full-length adult romantic Kunstmärchen, and T. $\mathrm{H}$. White's The sword in the stone (1938) uses its central transformation combat motif with the apprentice's tutor taking on a witch on his behalf (very widely disseminated and popularised through the Disney film and comic-book versions).

"The magician and his pupil" is foreshadowed in the tower, when James becomes Taykin's apprentice. After Aura makes James clever and escapes, it continues in the palace to which Taykin goes with 
James as cook and scullion (Aura has said she wants to be beautiful to get a job there). "The magician's heart" does not reverse the roles or functions of "The magician and his pupil", but does soften the motives and character of its prototype's evil sorcerer into a more sympathetic one, on the same lines as its refunctioning of the wicked fairy of "The sleeping beauty". The evil sorcerer of "The magician and his pupil", "the King of the Black Art", "the Black King of Morocco" has the sinister overtones of a kidnapper. It is never clear just why he needs or wants an apprentice. He takes his apprentice from his father, and says that "if he did not get him ere the seven years were expired, he would not get him at all; and where he was to find him he did not let him know" (Briggs 1970: 162 "The Black King of Morocco"). In variations, the evil sorcerer does not return with his apprentice as he promised. With Taykin, the word "merely" modifies "wicked magician" to obviate any hint of the sinister from the beginning, and to replace it with the comic. Though Taykin can curse, most of his magic is conjuring tricks. He is like a cook, and his book of spells is called a "recipe book". He does not seek for an apprentice or take him from his parents, and initially, he means his apprentice no harm. James has stupidly lost himself and been adopted by the baker's wife, and Taykin's nurse brings him along to do Taykin "a good turn". She advises him to take James as an apprentice, for company.

Sorcerers' apprentices in Kunstmärchen and fantasy short stories tend to be stupid and disobedient (eg. Nicholas Stuart Gray's "The Sorcerer's Apprentices", in Mainly in Moonlight:Ten Stories of Sorcery and the Supernatural, 1965), perhaps because of the apprentice in the variant Tale Type "The master and his pupil", which was very popular as a puppet play. This variant apprentice is "but a foolish lad" who calls up a devil or ghost or starts off a spell which he is then unable to exorcise or stop (Briggs 1970: 411, "The master and his pupil"). In English versions of "The magician and his pupil" itself, the apprentice is "deficient in the principal requisites of human education" though "he had been tutored in the best schools" (Briggs 1970: 162, "The Black King of Morocco"). Fortunatus/James is stupid like his prototypes in both the main tale and its variant, but he comes to the magician, not the other way around. Thus, "The magician's heart" substitutes the element of chance for its prototypes' sinister plotting. 


\section{Sanjay Sircar}

Unlike either of his Märchen prototype magicians, Taykin is quite aware of the dangers of taking an apprentice and teaching him his secret lore: “'And teach him my magic? Not me", he says to his nurse, for he knows that "It's no use advertising for a stupid person - you'd get no answers!"." The magician's heart' draws on the adage that a fool and his money are soon parted, for Taykin's nurse demonstrates James's stupidity by telling him to give Taykin his money. He obediently does so, and, “"My last doubts vanish," said the Magician, "he is stupid"."

Thus "The magician's heart" takes the master-magician and the stupid apprentice from "The magician and his pupil", and makes it comic. It also takes the princess's help, and harmonises it with elements from the other prototypes. In "The magician and his pupil", the princess hides the apprentice as a ring on her finger at the end. In "The magician's heart" the "Rickey"-derived motif substitutes for this, when Aura cures James of his stupidity in the middle (joining one "enchanted relative" tale to one "supernatural adversary" one). Having been helped by Aura, James's role in the second part is to grow and to help her. Hence, like her prototype princess in "The magician and his pupil", Aura is relatively passive in the palace, more a foil to James than before, more reliant on his advice and trickster-wit. So she cowers before Taykin who now knows her to be the princess, and threatens to make her drink a potion that will re-uglify her unless she marries him. She promises to obey her father and give up James in exchange for his sparing James's life, and trustingly follows James's covert signal to obey the King's order to promise to marry the suitor on her right hand.

Meanwhile, like his prototype apprentice, James grows to manhood and gets the princess by concealing cleverness and overcoming the older powerful male with his own magic weapons. Here, Nesbit both multiplies and provides a substitute for the prototype's magic transformation-combat. Taykin transforms himself into a red lion while James becomes a more powerful green dragon with the same spell as they follow Aura to the palace where James steals and learns from Taykin's magic book. James outwits the King (who has some of Taykin's function as older male adversary), as he transposes the positions of the two suitors, so that Aura has promised to marry him rather than his rival. This is not logically necessary, for James 
now knows that he is a prince, but it is aesthetically satisfying in following the prototype. Finally James reveals his own "transformation" into a prince and transforms Taykin, his erstwhile master, into a child.

Thus "The magician's heart" retains the outlines of "The magician and his pupil". It multiplies the older male adversary and the transformation combat, substitutes the princess's help, and makes the new apprentice somewhat stronger and more protective than the old one. "The magician's heart" does not introduce any new themes: the young man's movement from stupidity to trickster-wit and the deceptive affectation of continued stupidity till the confrontation are similar in the old tale and the new. But "The magician's heart" does introduce a new tone with its introduction of chance, comic touches, and characterisation of Taykin as human rather than sinister.

Formal modification of traditional retribution, substitution of brutality as a value by compassion, the new possibility of conversion

When she grows up, Aura as the princess in Taykin's power and the greater part of James's overcoming of Taykin come from "The ogre's (devil's) heart in the egg". Like "The magician and his pupil", "The ogre's heart" is a Märchen about the deception by a young man of an older supernatural male. But it is a much harsher tale, for it is also much more clearly about the delights of revenge. It is centred on a very old and very primitive notion and motif (Tolkien 1964: 2021 - On fairy stories $(1938,1947)$ ), the "external soul" (not always a villain's), also of Indian origin (Mitra-Majumdar 1907 "Sonar kathi rupor kathi" ("The gold stick and the silver stick"), "Nilkamal and Lalkamal", and "Dalim Kumar"), with its elaborations of the "soul in an egg", or a "life dependent on an external event or object". A version of it was collected by the Grimms, and Robert Lee Wolff (Wolff 1961) mentions a north German version in Benjamin Thorpe's Yule-tide stories (1853), which might also have been available to Nesbit, but the best-known transcribed version appears in Sir George Dasent's translation of Asbjornsen and Moe (1859). Today we know its central motif best from Stravinski's ballet "The firebird" (1910). 
My account of "The ogre's heart" draws on the Aarne-Thompson three-part summary of "The ogre's heart" and the details of Dasent's "The giant who had no heart in his body". In the first part six sons are turned to stone by the giant, but the seventh son, Boots, receives magic help from three creatures in three places, and they continue to give advice. In the second and third parts an ogre holds a princess captive. The hero comes to the ogre's lair seeking shelter. She hides him. She then coaxes the ogre to tell her the hiding place of his heart. Twice he lies to her, but at last, touched by her pretended love for him in decking the false hiding-places with flowers, he tells where his heart lies. It lies in an egg, and when Boots gets hold of it, he squeezes it to blackmail the giant into reviving his brothers, after which he squeezes the heart in two, the giant dies, and Boots marries the princess.

In Märchen mutation, forgetting leads to amplification by various means. "The magician's heart" amplifies "The sleeping beauty", "Rickey", and "The magician and his pupil" by conflation, and substitutes elements, sometimes so that they are harmonised with each other. But it omits no basic element from "The sleeping beauty" (Part I, usually told as an independent tale) and "The magician and his pupil"; and in relation to "Rickey" it does away with only the clever ugly sibling and the stupid princess forgetting her promise to marry Rickey and being persuaded into it, for these elements do not fit. It "forgets" - that is omits - basic elements only from "The ogre's heart", the elder brothers, and the animal helpers and their advice. As a result, James's role as an independent agent and protector of the princess is strengthened, for he takes advice and help from no-one else.

There are princesses in all four prototypes, but in "The magician and his pupil", the young man is low-born, at any rate not a prince, and in "The ogre's heart", he is a prince, but a low-ranking seventh son in his family. In "The magician and his pupil" and "The ogre's heart", this relatively low social or familial status exemplifies the power of independent action to succeed in the world, even from a disadvantaged position. "The magician's heart" harmonises the powerful young prince of its first two prototypes with the lowly placed young man and prince of the second two prototypes, by giving its own young man a dual aspect, the roles of both Fortunatus and 
James. Thus, "The magician's heart" has it both ways: incorporating and harmonising the class parity of the lovers of the "enchanted relative" prototypes with the class disparity of the lovers and the low-status seventh prince of the "supernatural adversary" prototypes.

In "The magician's heart", Taykin, as the modern human conjurer, substitutes for the traditional princess's ogre-captor, as he has done for the wicked fairy. His ogre-stronghold is multiplied (doubled): his tower detains Aura who cannot open the locks to escape, and in the palace kitchen he threatens and tries forcibly to detain her. But from the start, these new strongholds indicate that Taykin is less fearsome and self-containedly powerful than the ogre. The tower is his prison, in the palace kitchen he is a servant, a cook. Then, just as James is not a sinisterly engaged apprentice, Aura, unlike her prototype, is not actually Taykin's captive, though she is in his power for a time. The prototype princess deceives the ogre that she loves him for Boots's sake, Aura deceives Taykin about her identity for her own sake.

In "The magician's heart", in both tower and palace, captor, princess and prince are together when the secret of the separable heart is revealed. The prince is hidden in the prototype, ignored in the new tale. As in "The ogre's heart", the captor's infatuation for the princess makes him reveal the secret of his separable heart. But in "The ogre's heart", the ogre lies to her the first two times she coaxes him to tell her his secret, she is successful only on her third attempt, and the ogre's heart is securely hidden in an egg in a duck in a well in a church on an island in a lake far away (or an equivalent of this series). There is no such coaxing nor any such security arrangements in "The magician's heart", for Taykin reveals his separable heart of his own volition as he offers it and himself to Aura in the tower, then leaves it carelessly on the shelf in the palace kitchen. He proposes to Aura when he thinks she is a beggar maid, which is pleasantly democratic of him. He is thus better-natured, less predatory and more foolish and careless than the ogre of "The ogre's heart".

The "external heart", the blackmail by squeezing it, the reneging on an implicit compact, and the brutal murder of the ogre are potentially nasty images. Overcoming the ogre is much harsher than 
overcoming the other prototype's magician. In Märchen versions there tends to be much squeezing of the heart, as many as three to four times, though it is recounted summarily (Frazer 1974: 876, 878, 879, 880-888, 971). In Dasent's version,

the Wolf told [Boots] to squeeze the egg, and as soon as ever he squeezed it the Giant screamed out.

"Squeeze again," said the Wolf; and when the Prince did so, the Giant screamed still more piteously, and begged and prayed so prettily to be spared, saying he would do all that the Prince wished if he would only not squeeze his heart in two".

[The Giant succumbs to the Prince's blackmail and resuscitates Boots's brothers.]

"Now squeeze the egg in two," said the Wolf. So Boots squeezed the egg in pieces, and the Giant burst at once.

(Dasent 1937: 119, unattributed edition, a selection from Popular tales from the Norse, 1859)

"The magician's heart", in contrast, diverts attention from the repulsiveness of the "external heart" and softens the prototype's plot. First, it foregrounds how fantasy has brought a figure of speech to life when Taykin says to Aura, "I hereby offer you my hand and heart" and "He put his hand into his waistcoat and pulled out his heart". And it ironically underscores the difference between real life and works of fantasy when Taykin tells Fortunatus to be careful, "That's my heart you've got there. My life's bound up in it" and Fortunatus replies "That's often the case with people's hearts." Second, the blackmail-situation arises for even a briefer moment than in "The giant's heart", its horrifying potential is softened by the omission of any squeezing or murder, any reneging on a compact, and by the comic mock-melodrama of James's threats and Taykin's terrified "skipping" in response.

All fantasy fiction allows for metaphorical shorthand, and the fantasy motif of the "external soul" in the particular form of the separable heart can emblematically imply that mere strength or supernatural power is no guarantee of safety, that threatening power always has a vulnerable point, that the most elaborate precaution cannot render evil invulnerable to the resources of goodness, that weakness allied to alertness and sometimes low cunning can turn 
the strength of an unwary enemy into a weakness, and attack him indirectly. These are the moral implications of all such stories since David and Goliath. "The magician's heart" shares them with "The ogre's heart", but the characterisation of Taykin, unlike that of the ogre, makes Taykin's detachable heart, his literal heartlessness, stand both for his power and also his lack of love: not being allowed to give love to the babies at the christenings, then not allowing himself to feel anything other than spite. Hence, Taykin's suppression of human emotions renders him vulnerable when he finally allows himself to feel them, and he falls in love with Aura.

"The magician's heart" moves firmly away from the feudal social order implied by the Märchen and from its one-faceted characterisation to a different view of personal potential. In Märchen, "There is no saving of the wicked in heart. Their fate is to have inflicted on them the evil they would inflict on others" (Opie 1972: 14). Transcribed versions often modify this. The sisters of Perrault's Cinderella beg and receive forgiveness, though their eyes are pecked out in the Grimms. But the Kunstmärchen can - and Nesbit does integrally allow for the possibility of change in order to do away completely with the retributive justice of the Märchen genre (though it retains the prototype's deception and blackmail) and replace it with compassion. James first lets Taykin go, then the King spares him in exchange for information and accedes to the nurse's plea not to punish Taykin at all.

The narrator mentions the nurse's descriptions of Taykin as a fatlegged infant right at the beginning before he turned wicked, and at the end he is turned back into that infant. Thus, these references, like the one about James's goodness and strength, are a narrative hook. James's turning Taykin into a child, the equivalent of a transformation in terms of power in relation to "The magician and his pupil", is also a conversion in terms of morality in relation to "The ogre's heart". Taykin cannot be made good, but the badness can be taken out of him, a verbal quibble which allows the possibility that he can be made innocent. And "The magician's heart" presents that conversion to innocence in an external emblem in the mode of the Märchen, which does not psychologise or explore mental states but makes everything external (Lüthi 1970: 124). So, "The magician's heart" mitigates the inherent nastiness of the "external soul" motif 
Sanjay Sircar

and traditional plot, as it presents the love of benevolent providential White Witch for her charge, of the prince and princess for each other, of even the magician and his nurse along the way, and as it ends happily for all.

Thus, "The magician's heart" re-presents the guileful disadvantaged youth growing to adulthood and overcoming an older male of "The ogre's heart". But "The magician's heart" makes that youth more independent of others' help and advice, adds a gendered inflexion to the helpful captive princess, a class inflexion to the love of her supernatural adversary for her, greater touches of weakness to that supernatural adversary, comic touches to the way he is overcome, and a softening of the amorality and retribution of the prototype. "The magician's heart" retains the value of love from the moral order of the "enchanted relative/curser" Märchen, but altogether reverses the value of brutal final punishment of the "supernatural adversary" Märchen into compassion, the possibility of conversion, and an inclusive society which is unlike that of a Märchen world.

The second part of "The magician's heart" does, indeed, introduce fewer new inflexions into its prototypes than the first, in which these are very much more obvious. Hence, we may evaluate "The magician's heart" as a tale balanced between a newer and an older world-view. Or we may take the second part, even with its new tones and values, as tending to push the narrative in the direction of safe traditional closure, not really moving away from the blue and pink which gender the babies at the beginning, not really addressing class hatred its final incorporation of Taykin. I tend towards the first opinion, though I would not overstress the alien new inflexions over the traditional ones.

\section{CONCLUSION}

This discussion of "The magician's heart" has shown ways in which this particular Kunstmärchen self-consciously works with and parodies its Märchen prototypes, "The sleeping beauty", "Rickey with the tuft", "The magician and his pupil", and "The ogre's heart in the egg". Nesbit's Kunstmärchen derives from various Märchen, as a Märchen derives from its previous versions. A sense of the same common pool of traditional inherited material (motifs, tale-types, 
themes, tones, values) is present in both the Märchen and Kunstmärchen genres, and a bygone traditional folk genre and a subsequent modern present popular genre both operate in similar ways in relation to that pool. An individual Märchen generically resembles other Märchen, and those in its own particular category of tale-types. Similarly, an individual Kunstmärchen generically resembles Märchen, and over time, other Kunstmärchen like it.

We see that an individual, named modern author who writes a Kunstmärchen to be printed (and reprinted in exactly the same words) for a group of readers (children) at a specific time can assemble a contaminatio-Kunstmärchen using literary techniques which resemble the processes of mutation which occur as a sequence of many anonymous oral tellers retell a Märchen to groups of listeners (adults and children) over various times and places. Both "forget" and leave out previous material, both amplify material by drawing in new material from other tales, both substitute elements, and both iron out inconsistencies between them in their new relation to each other.

A Märchen can be retold in a different language, the inventiveness of an individual folk-teller can lead to intentional variations to for better or worse, and then, transcription and bowdlerisation by scholars and writers often change it more purposefully for stylistic and didactic (ideological) reasons (Aarne 1913: 23). It can be then expurgated, moralised, told comically, dramatised. Yet a Märchen which has travelled and mutated remains the same tale in a new version; its relation to the common pool of material is always relatively naive. But a pastiche-Kunstmärchen which has been written out of motifs from one or more previous Märchen or a contaminatioKunstmärchen which has been assembled out of many of them is another new, discrete independent work, not a new version. The writer's deliberate alterations to old material out of formal and generic aesthetic choices and out of ideological ones, will always have the parodic self-consciousness of all second-order work, and the Kunstmärchen's relation to the common pool is always relatively faux-naive. A Kunstmärchen can (though not all need to) echo and silence generic Märchen features, evoke and repudiate the Märchen world, use the power of the familiar magic of traditional narrative and reflect upon (implicitly criticise) it, assent to some part of the traditional world view and suggests some aspects of an alternative 
one. Nesbit's burlesque Kunstmärchen “The magician's heart" does just this.

The above analysis of one Kunstmärchen by a major author in the genre in the context of its sources suggests to me a possibly useful set of questions to be asked when a Kunstmärchen comes to hand, in order to describe it accurately, which is a prerequisite for evaluation. Does it "draw upon" ("derive from" and "reversion") a particular Märchen, or more than one, or resemble those in a traditional group (eg. the "enchanted relative"), i.e. is it a pastiche or a contaminatio? Or does it only draw upon isolated motifs from a wide variety of groups, and if so, how many, which ones and at what level of particularity (a princess, an enchanted princess, an enchanted princess in a tower...)? Having established either a source or sources or a group of motifs, how far in general does it draw upon the common stock of inherited traditional narrative material, that is, how close or far from that stock is it? If it bears only a few traces, is it perhaps a fantasy short story and not a Kunstmärchen at all? If it is definitely a Kunstmärchen, formally, what has been omitted/forgotten, telescoped, added from external sources, substituted, and harmonised? What new, alien inflexions, themes, tones and values are present? On balance, do these make the work more similar to or more different from the Märchen genre? After these questions have been answered (and it only takes a moment), then, and only then, can we begin to ask: is it well done, do we like it, why?

In the above description of "The magician's heart", I have dealt only partially with the new tones, the comic touches (the doubled babies, Taykin as human magician and ogre), for I have been dealing with "The magician's heart" primarily in relation to its prototypes/ sources. But the Kunstmärchen genre tends to go in the direction of three tones: the hortatory and instructive (with the allegorical variety), the preciously etiolated and mysterious (with the romantic variety), and the comic (with the burlesque variety). Each variety (tonal group) has evolved its own generic decorum, so that a particular Kunstmärchen reminds us not only of works in the Märchen genre and the genre as a whole but of the genre as a whole and also of other previous Kunstmärchen, particularly those of its own variety. So two other questions should be asked in relation to a particular work: how far does a Kunstmärchen accord with the generic decorum of the Märchen genre, and how far does it 
accord with the generic decorum of its own variety insofar as this is different? There are many more ways in which "The magician's heart", as a work in the Kunstmärchen genre, accords with the generic decorum of the Märchen genre, and many other comic touches, techniques and tones which accord with those of the burlesque Kunstmärchen variety to make "exactly the right mixture of mirth and magic". These remain to be explored.

\section{Comments}

This is the first part of a five-part project: the other parts analyse the relation of the plot of "The magician's heart" to that of New Comedy, delineate the differences between the 1907 stage and 1912 discursive prose versions of (articles in Marvels and Tales), exemplify the generic decorum of the burlesque Kunstmärchen in relation to the Märchen genre, and compare it with a similar romantic Kunstmärchen. I corresponded with Mrs Julia Briggs, Nesbit's latest biographer, while she was conducting her research, and I am indebted to her letter directing me to Stravinski's "The firebird" (1979). I am indebted to Mr Bill Tully, National Library of Australia, and Mr Arvind Kalia, Australian National University, for bibliographical help, and to Dr Linda Conrad, Griffith University, Queensland, for conceptual input. Extracts from the relevant French and German material were translated by Dr A. N. Burkitt, Australian National University. The text used is from E. Nesbit 1959.

${ }^{1}$ Only two other Kunstmärchen of hers were posthumously collected, "Princess Zuleika of Rosyposia" and "The Last of the Dragons" (in Nesbit et al. 1925).

\section{References}

Aarne, A. 1913. Leitfaden der vergleichenden Märchenforschung. Folklore Fellows communications, Vol. 2, No. 13. Reprinted in 1959, in a volume containing Nos. 13-15. Hamina: Suomalaisen Tiedeakademia, pp. 1-86, 23-39

Aarne, A. \& Thompson, S. 1961. The types of the folk tale: a classification and bibliography (Aarne's Verzeichnis der Märchentypen, tr. and enlarged; 2nd. ed.). Helsinki: Finnish Academy of Sciences.

Armstrong, D. L. 1974. E. Nesbit: an entrance to "The magic city". Ph.D. thesis. John Hopkins University Press.

Asbjornsen, Peter Christen \& Moe, Jorgen 1988. Popular Tales from the Norse. George Webbe Dasent (trans.). Edinburgh: David Douglass.

Asbjornsen, Peter Christen \& Moe, Jorgen 1970. East o' the Sun and West o' the Moon. George Webbe Dasent (trans.). New York: Dover. 


\section{Sanjay Sircar}

Brereton, G. 1957. Introduction. Fairy tales. By Charles Perrault, trans. by G. Brereton. Harmondsworth: Penguin.

Briggs, K. M. 1970. A dictionary of British folk tales in the English language, Part A, Vol. 1. London: Routledge and Kegan Paul.

Cosquin, E. 1912. Les mongols et leur pretendu role dans la transmission des contes indiens vers l'ocident europeen: etude de folklore compare sur l'introd. du Siddhi-kur et le conte du magicien et son apprenti. Revue des traditions populaires, 27.

Croxon, M. 1971. A study of Edith Nesbit. M.A. thesis. University of Birmingham.

Dasent, Sir G. W. 1937. The giant who had no heart in his body. East o' the sun and west o' the moon. Akron, Ohio: Saalfield.

Ellis, A. 1974. E. Nesbit and the Poor. Junior bookshelf, Vol. 38, No. 2. (April), pp. 73-79.

Frazer, Sir J. G. 1974 [1922]. The golden bough: a study of magic and religion. Abridged ed. London: Macmillan.

Green, R. L. 1995. Introduction. Modern fairy stories. London: J. M. Dent, pp. $\mathrm{xv}-\mathrm{xvi}$.

Lüthi, M. 1970. Once upon a time: the nature and meaning of fairy tales. Trans. by L. Chadeayne and P. Gottwald. New York: Ungar.

Mitra-Majumdar, D. 1907. Thakurmar jhuli [Grandmother's bag: mothers' tales collected from Bengal]. Calcutta: Mitra and Ghosh.

Nesbit, E. 1887 [1886]. Lays and legends. 2nd edition. London: Longmans, Green and Co.

Nesbit, E. 1908. Ballads and lyrics of socialism. London: Fabian society and A. C. Fifield.

Nesbit, E. et al. 1925. Five of Us - and Madeline. New York: Coward McCann.

Nesbit, E. 1959. The Magic World. London: Ernest Benn, pp. 260-280.

Opie, I. \& P. (eds.) 1972. The Classic Fairy Tales. London: Oxford University Presss.

Rahn, S. 1985. "News from E. Nesbit: The Story of the Amulet, and the Socialist Utopia'. English literature in transition, 1880-1920, Vol.. 28, No. 2, pp. 124-144.

Scherf, W. 1974. Family Conflicts and Emancipation in Fairy Tales. Children's literature, 3, pp. 77-93.

Thorpe, B. 1853 (1968). Yule-tide stories; a collection of Scandinavian and north German popular tales and traditions, from the Swedish, Danish, and German. London: Bohn.

Tolkien, J. R. R. 1964. On fairy stories. Tree and Leaf. London: Unwin.

Wall, B. 1991. The Narrator's Voice: the Dilemma of Children's Fiction. London: Macmillan.

Wolff, R. L. 1961. The Golden Key: a Study of the Fiction of George MacDonald. New Haven: Yale University Press. 